\title{
Pesticide Toxicity Profile: Coumarin and Indandione Rodenticides 1
}

Frederick M. Fishel ${ }^{2}$

This document provides a general overview of human toxicity, provides a listing of laboratory animal and wildife toxicities and a cross reference of chemical, common and trade names of coumarin and indandione rodenticides registered for use in Florida.

\section{General}

Rodenticides pose risk for accidental poisonings for several reasons. They are agents specifically designed to kill mammals; often their toxicity is very similar for the target rodents and for humans. Since rodents usually share environments with humans and other mammals, the risk of accidental exposure is an integral part of the placement of baits for the rodents. As rodents have developed resistance to existing rodenticides, there is a continuous need to develop new and potentially more toxic rodenticides. There are currently three active ingredients belonging to the coumarin rodenticide family registered for use in Florida: brodifacoum, bromadiolone, and warfarin. Brodifacoum was first registered in 1979. It is registered for controlling rats and mice in and around structures, households, industrial sites, and 
Indandiones are not only anticoagulants; they also uncouple oxidative phosphorylation (energy generation) in mammals. Chlorophacinone and diphacinone have both general and restricted use products on the market. The general use products tend to be formulated as low percentage ready-to-use and carry the signal word, "CAUTION," whereas some of the restricted products have "WARNING" on their labels. Chlorophacinone and diphacinone products that are restricted are classified as such because EPA considers them to possess high acute oral toxicity.

\section{Toxicity}

Warfarin and related anticoagulant compounds are the most commonly ingested rodenticides in the United States, with 13,345 exposures reported in 1996 alone, approximately $96 \%$ unintentional, but others with suicidal intent. These materials are readily absorbed into the gastrointestinal tract. Warfarin can be absorbed across the skin, but this has occurred only under extraordinary circumstances. It usually takes several days for warfarin ingestion before a rodent dies because of the long half-lives of the vitamin K-dependent clotting factors. Lethal hemorrhage may follow smaller doses of the modern, more toxic compounds, such as brodifacoum. These compounds have been called "superwarfarins" because their toxicities are much greater than warfarins (Table 1). Effects of these rodenticides on humans include bleeding symptoms, but also cause anemia, and fatigue. Severe cases progress into shock and death. Over the years, these compounds had clinical uses and are widely known for therapeutic anticoagulant effects, but warfarin has been established as a human teratogen, because it causes birth defects in the offspring of women receiving blood-thinning treatment with the compound during any trimester of pregnancy. No information is currently available on warfarin's reproductive, mutagenic, and carcinogenic effects. The use of diphacinone in humans as an anticoagulant drug has been apparently discontinued. Diphacinone was not shown to be mutagenic, but there are no data currently available on its reproductive, teratogenic, and carcinogenic effects. Studies with cattle indicate a high tolerance to diphacinone; it is used in Latin America for controlling vampire bats preying on cattle. Ecologically, the main concern with the coumarins and indandiones is secondary poisoning. Mortality is a likely result in wildlife which feed on rodents that have ingested these compounds. Bromadiolone and brodifacoum are also toxic to fish, should sufficient amounts reach water sources. Mammalian toxicities for the coumarin and indandione rodenticides are shown in Tables 1 and 2, respectively. Tables 3 and 4 list the toxicities to wildlife, if known, by the common name of the pesticide. Tables 5 and 6 provide a cross listing of some of the trade names that these products are registered and sold by in Florida.

\section{Additional Information}

Crop Protection Handbook. 2005. vol. 91. Willoughby, Ohio: Meister Publishing Co. http://www.meisterpro.com/mpn.

Koehler, P.G. and W.H. Kern, Jr. 2005. Rat and mouse control. UF/IFAS EDIS Document ENY-224. http://edis.at.ufl.edu/DH044.

Litovitz, T.L., M. Smilkstein, L. Felberg, et.al. 1997. 1996 Annual report of the American Association of Poison Control Centers Toxic Exposure Surveillance System. Am. J. Emerg. Med. 15:447-500.

Nesheim, O.N., F. M. Fishel and M. A. Mossler. 2005. Toxicity of pesticides. UF/IFAS EDIS Document PI-13. http://edis.ifas.ufl.edu/PI008.

Reigart, J.R. and J.R. Roberts. 1999. Recognition and management of pesticide poisonings, $5^{\text {th }}$ ed. United States Environmental Protection Agency Publication EPA-735-R-98-003.

Seyler, L.A., et.al. 1994. Extension toxicology network (EXTOXNET). Cornell University and Michigan State University. http://extoxnet.orst.edu/index.html. Visited July 2005. 
Table 5. Cross reference list of common, trade and chemical names of coumarin rodenticides.

\begin{tabular}{|c|c|c|}
\hline Common name & Trade names* & Chemical name \\
\hline Brodifacoum & $\begin{array}{l}\text { D-Con } \AA \text {, Enforcer } \AA \text {, Havoc } \AA \text {, } \\
\text { Jaguar } \AA \text {, Talon } \AA \text {, others }\end{array}$ & $\begin{array}{l}\text { 3-[3-(4-bromo[1-1-biphenyl]-4-yl)-1,2,3,4-tetrahydro-1- } \\
\text { napthalenyl]-4-hydroxy-2H-1-benzopyran-2-one }\end{array}$ \\
\hline Bromadiolone & $\begin{array}{l}\text { Contrac } \AA \text {, Hawk®, Maki®, } \\
\text { Tomcat } \AA \text {, V Rat } \AA \text {, others }\end{array}$ & $\begin{array}{l}\text { 3-[3-(4-bromo[1-1-biphenyl]-4-yl)-3-hydroxy-1-phenylpropyl]- } \\
\text { 4-hydroxy-2H-1-benzopyran-2-one }\end{array}$ \\
\hline Warfarin & Bonide $\AA$, Kaput $\AA$, Rodex $\AA$, others & 3-(a-acetonylbenzyl)-4-hydroxycoumarin \\
\hline
\end{tabular}

Table 6. Cross reference list of common, trade and chemical names of indandione rodenticides.

\begin{tabular}{||l|l|l||}
\hline \hline Common name & Trade names ${ }^{*}$ & Chemical name \\
\hline Chlorophacinone & Enforcer $\Theta$, Rozol $\Theta$, others & $\begin{array}{l}2-[(4-\text {-chlorophenyl)phenylacetyl]-1H-indene-1, } \\
3(2 \mathrm{H}) \text {-dione }\end{array}$ \\
\hline Diphacinone & Ditrac $\Theta$, Ramik $\AA$, others & 2 -(diphenylacetyl)-1,3-indandione \\
\hline${ }^{*}$ Does not include manufacturer's prepackaged mixtures. \\
\hline \hline
\end{tabular}

